\title{
A Longitudinal Assessment of Tax Reforms and National Income in Nigeria: 1971-2014
}

\author{
Innocent Augustine Nwaorgu ${ }^{1}$, Wilson E. Herbert ${ }^{2} \&$ Francis Onyilo $^{2}$ \\ ${ }^{1}$ Department of Accountancy, Faculty of Management Sciences, Chukwuemeka Odumegwu Ojukwu University, \\ Uli, Anambra State, Nigeria \\ ${ }^{2}$ Department of Accounting, Banking \& Finance, Faculty of Management \& Social Sciences, Baze University, \\ Abuja, Nigeria \\ Correspondence: Wilson E. Herbert, Department of Accounting, Banking \& Finance, Faculty of Management \& \\ Social Sciences, Baze University, Abuja, Nigeria. Tel: 234-803-602-5258. E-mail: weherbert12@ gmail.com
}

Received: May 28, 2016

Accepted: June 12, 2016

Online Published: July 25, 2016

doi:10.5539/ijef.v8n8p43

URL: http://dx.doi.org/10.5539/ijef.v8n8p43

\begin{abstract}
This study assesses the impact of tax reforms on Nigeria's national income over the period, 1971 to 2014. Using a variety of growth indicators signifying tax reforms, our regression model specified growth rate of national income (proxied by GDP) as a function of growth rates in these indicators. Diagnostic tests (F-statistics, Adjusted R-Square and Durbin-Watson) were carried out to ascertain the robustness of the parameter estimates. We found that tax reforms significantly improved national income and economic growth during the period of study, especially growth rates of value added tax and personal income tax. Our results show that growth rate of personal income tax has a positive significant effect on the national income and economic growth, while that of value added tax has a negative significant effect on growth of national income. The growth components of company income tax and petroleum profit tax are positive but not statistically significant. On the other hand, reforms in custom and excise duties were found to yield negative and statistically non-significant effect. The leading conclusions from these findings are: (1) strategic tax reforms significantly influence the behaviour of national income and GDP; (2) tax policy significantly fosters the growth of national income; and (3) policy makers, especially Ministry of Finance and Federal Inland Revenue Service and their state counterparts, should give requisite attention to tax policy issues, in the light of their obvious implications on growth of the national income and economic development.
\end{abstract}

Keywords: fiscal federalism, gross domestic product, longitudinal assessment, national income, Nigeria, tax reforms

\section{Introduction}

Tax is one of the primary sources of public revenue to governments across the world. It is equally the oldest source of revenue as well as an important fiscal policy tool of most governments. From the days of petrodollars in the 1970s to late 2014 when crude oil prices crashed in the international markets, tax was a subordinate source of revenue for the Nigerian Government. Prior to military incursion into Nigerian governance in 1966 and the resulting Centralist Federal government followed by the Civil War, Nigeria operated a regionalist federalism. The context and content of regional federalism was predicated on fiscal federalism. The term 'fiscal federalism' is a euphemism for fiscal decentralization. It connotes a decentralized system of government in which the scope and structure of the constitutional tiers or levels of government (Federal, State, and Local), their associated establishments are clearly delineated and national resources shared accordingly to enable the three tiers to perform their respective constitutional accountabilities and functions. Nigeria's constitutional negotiations were based on devolution of sovereignty to the regional governments, namely: Eastern region, Northern region, and Western region. Incidentally, these were the three dominant ethnic nationalities and languages in Nigeria before and after independence.

These constitutional arrangements were framed under the natural assumption of economic and fiscal federalism, which was in existence before, during and after the independence in 1960. However, following the military coup that swept away the nascent political structure of the new independent Republic of Nigeria and ushered in a military government in 1966, the federalist system was abolished in favour of a unitary system. Although states 
were later created across the three regions, they were not constitutionally disposed to function with the fiscal autonomy of the regions. In 1979, Nigeria witnessed a return to a constitutional Federalist presidential system from the spate of military interregnums that characterized the period, 1966-1979. This time around, the Presidential Federalist structure created the Federal Capital Territory, Abuja. Further, the 1979 constitution recognized the States and local governments as constituting the second and third tiers of government within the federation.

Taxation started in the Northern part of Nigeria in the 1800s, long before the advent of the colonial administration. Then, the Emirs operated an efficient and organized system of taxation based on Islamic precepts. This framework facilitated the introduction of indirect rule in Nigeria by the British government during the colonial era. By 1904, various community taxes were consolidated under the Land Revenue Proclamation Law. In 1906, the community taxes were further consolidated under the Native Revenue Ordinance (Somorin, 2012). After the amalgamation of the Northern and Southern Protectorates in 1914, there was a need for additional revenue by the British government to administer other parts of Nigeria. This quest for additional revenue necessitated the extension of the tax system to the Western and Eastern parts of the country. Thus, taxation, which had been in existence in the Northern Protectorate, took effect in the Western and Eastern parts of Nigeria in 1917 and 1928, respectively (Odusola, 2006). Over the decades since then, the Nigerian tax system has witnessed a series of reforms which were not necessarily informed or induced by the country's level of economic activities. The trajectory of taxation has historically intrigued policy makers and researchers alike. The interest is on how taxation interaction effects play a pivotal role in the economy. Tax reform is a fiscal policy strategy designed to enhance tax administration. Essentially, it entails changing the way taxes are collected or managed by the government with a view to improving national income and gross domestic product, and providing economic and social benefits to the citizenry.

The empirical sustainability of this view is what this paper sets out to interrogate, given the fact that economic and political reforms which have worked well in other developing countries, such as Brazil, Ghana, India, Malaysia, and Mexico, have yielded abysmal results in Nigeria. The purpose of this study is to assess the impact of changes in Nigeria's tax structure (proxied by tax reforms) on national income over the period $1971-2014$. Specifically, the study seeks to determine the nature of the impact of value added tax, personal income tax, company income tax, custom and excise duties, petroleum profit tax and total tax revenue on national income. The nature of the relationship among these variables is also examined.

The rest of the paper is structured as follows. Following this introduction is the literature review, in Section 2, which explores the episodes of tax reforms in Nigeria and other relevant literature on tax reforms, including the theoretical framework. Analytical framework and methodology of the study is sketched in Section 3. Section 4 discusses the econometric results and their implications on Nigeria economy. Section 5 concludes with recommendations and policy implications.

\section{Literature Review}

There is a large literature on the impact of taxation on the economic growth of a nation. Over fifty years ago, Kaldor (1964) espoused the importance of taxation, as a major source of government revenue, in accelerating economic development. In addition to being a major source of revenue for financing government's socioeconomic development agenda, taxation, especially the progressive genre, enables government to distribute wealth more evenly among its citizenry as well as serves as automatic fiscal stabilizer to cushion the effects of economic cycles. Recently, other studies such as Brown (2002), Padovano and Galli (2002), Wang (2007) and Ogbonna and Appiah (2012) have highlighted the significant impact of taxation on national economic growth. For example, Padovano and Galli evaluated the robustness of the correlation between tax variables and growth by progressively including additional policy and control variables in the growth regression. Ogbonna and Appah (2012) had investigated the relationship between tax reforms and economic growth in Nigeria (proxied by GDP), using reforms on petroleum profit tax, company income tax, value added tax, personal income tax, education tax and customs and excise duties as explanatory or independent variables. They found in the main that tax reforms have a significant positive impact in the functioning of government and on national economic growth.

Whatever the prevailing political ideology or dispensation of any country, it must steadily expand the repertoire of non-revenue yielding services, such as education, health, infrastructure, and social security. Toye (1978) likened that the link between taxation and economic development to the link between a universal desire and a government action designed to be a means to an end. Research has shown that one of the most important policies on which most economists agree is that emerging nations must increasingly mobilize their own internal resources in the pursuit of economic development and growth (Wilford \& Wilford, 1978). To be sure, there is virtual 
unanimity with the proposition that taxation is an indispensable internal source of revenue for a nation. Thus, an effective tax policy is one that is not only progressive but also ensures that every taxable citizen voluntarily pays their taxes as and when due. However, getting this policy right is both a desideratum and a challenge in Nigeria and the Sub-Saharan Africa (SSA) in general.

Progressive governments are continually evaluating and re-evaluating strategies of improving their public finances. Just as taxation is a leading source of public revenue for governments, so is tax reform an important strategy at the disposal of government. Tax reforms can be either progressive or retrogressive and dysfunctional. A progressive tax system is one that (a) is growth-oriented, (b) aggressively seeks to minimize the distortions of market signals by the tax system, and (c) promotes convergent expectations, serving in this way to attenuate uncertainties and obstacles to investment, innovation, entrepreneurship and other drivers of economic growth. Tax reforms may be designed to support GDP per capital growth which essentially entails shifting tax burden, or part thereof, from income to consumption and residential property and a greater role for environmental taxes and fees (OECD, 2010). Over the past forty years, tax reform strategies have allowed policymakers (principally, Federal Ministry of Finance and Federal Inland Revenue Service and their States' counterparts) to implement a range of tax reforms.

Taxation has both positive and negative effects on economic growth. Tax policy can affect growth rate in the economy through the decisions of economic agents. An increase in taxation reduces investible funds. Lower returns mean less disposable income and less funds for growth. There is a virtual consensus that a well-designed tax policy has the potential to raise economic growth, but there are many stumbling blocks along the way and certainly no guarantee that all tax changes will improve economic performance. However, increased public expenditure, such as investment in infrastructure, public education, and health care, can enhance productivity. Taxation provides the means to finance these public expenditures which, in turn, contribute to an increase in economic growth and development. In other words, there exists a relationship between tax revenue and the level of economic growth and development. This is consistent with Musgrave's (1969) hypothesis that the level of economic development has a strong impact on a country's tax base, and tax policy objectives vary with the stages of development. Also, the economic criteria by which tax structure is to be judged and the relative importance of each tax source vary over time (Musgrave, 1969). For instance, during the colonial era and immediately after Nigeria's independence in 1960, the sole objective of taxation was to raise revenue. Later on, the emphasis shifted to the protection of infant industries and income redistribution (Ajakaiye \& Odusola, 1996).

Tax revenue has been a key source of instability in a country's budget (Ekeocha, Ekeocha, Malaolu, \& Oduh, 2012). Consequently, the development of a country's sources of revenue should consider certain properties of tax bases such as persistence, volatility, and sensitivity. Tax reform allows policymakers to continually improve administration of the tax system and ensure that the reforms progressively reflect changing circumstances in the economic, social and political life of the nation. Musgrave and Musgrave (2004) identify the beneficial effects of tax to include "micro effects on the distribution of income and efficiency of resource use as well as micro effect on the level of capacity output, employment, prices, and growth". Following economic theory, it is expected that any change in tax system or structure will affect consumption, investment, and savings (Jhingan, 1995). The author further observes that economic variables such as investment, private consumption, and government consumption expenditure stimulate economic growth and growth in government income through taxation.

Over the years, successive Nigerian Governments have made attempts to transform and diversify the country's revenue generation base. Since the emergence of petrodollars in 1973, crude oil has been Nigeria's major revenue earner, including foreign exchange. Attempts - in the mid-1980s, 1991, 2003, and the yearly amendments in the annual budget estimates - at diversifying the economy away from over-dependence on oil revenue to refocus more on non-oil sources have not yielded much impact, especially in its structure and administration. Oil was discovered in Nigeria in 1958, but it is the attendant flows of petrodollars from the early 1970s onwards that became a curse rather than a blessing to the country. Oil revenue became not only the mainstay of the three tiers of Government (Federal, State and Local) but also a scourge of life for both governments and oil-producing communities. Oil revenue euphemistically became 'national cake' to be 'shared' by Governments and their agencies. For example, in a literal sense, the monthly Federation Accounts Allocation Committee (FAAC) meetings between Federal and State governments are specifically for the sharing of federal revenue - qua oil revenue, or better still, national cake. Even the private sector, such as banks, rely heavily on oil revenue shared during these monthly FAAC meetings.

Oil revenue exacerbated the scourge of corruption and indolence in both the national and private lives of Nigeria's elite political and economic class. The deliberate failure of the Nigerian leadership or inattention to diversify the economy and expand the country's revenue base contributed in the main to make the country a 
victim of the curse of oil. In Nigeria's context, this oil curse manifested in a plethora of moral hazards, of which the following are leading: indolence, official corruption, lack of accountability and transparency by Nigerian National Petroleum Corporation (NNPC), emergence of a rentier class, prebendalism, squandermania, and the alienation of the poor by the rich. While most countries afflicted by the curse of oil have found it difficult to escape from it, Nigeria's scenario is exacerbated by the identified moral hazard problems. The power of crude oil in Nigeria's socioeconomic and political development is founded on the statistics that crude oil accounts for $90 \%$ of Nigeria's exports, $70 \%$ of Federal revenue and about $15 \%$ of GDP. With respect to non-oil tax revenues, various reform efforts have been undertaken over the years. From the colonial era to 2004, Nigeria witnessed at least 24 important tax reforms. The year 2004 alone produced 10 tax reforms or amendments. Table 1 presents a summary of these.

Table 1. Timeline of major tax reforms in Nigeria, 1900-2014

\begin{tabular}{|c|c|}
\hline Year & Description \\
\hline 1904 & Land Revenue Proclamation Law \\
\hline 1906 & Native Revenue Ordinance \\
\hline 1943 & Autonomy granted to Nigerian Inland Revenue \\
\hline 1957 & Introduction of the Raisman Fiscal Commission \\
\hline 1958 & Formation of Inland Revenue Board \\
\hline 1959 & Petroleum Profit Tax Ordinance (PPT), No 15 \\
\hline 1961 & $\begin{array}{l}\text { Income Tax Management Act (ITMA), } \\
\text { Personal Income Tax Lagos Act }\end{array}$ \\
\hline 1967 & Establishment of the Lagos State Inland Revenue Department \\
\hline 1979 & Promulgation of Company Income Tax Act (CITA), C174 \\
\hline 1990 & $\begin{array}{l}\text { Capital Gains Tax Act (CGTA), } \\
\text { Minerals and Mining Act, } \\
\text { Stamp Duties Act }\end{array}$ \\
\hline 1993 & $\begin{array}{l}\text { Finance (Miscellaneous Taxation Provisions) (Amendment) Decree No 3, Establishment of the Federal Inland } \\
\text { Revenue Service (FIRS) }\end{array}$ \\
\hline 1998 & Tax and Levies (Approved List for Collection) \\
\hline 1999 & Constitution of Federal Republic of Nigeria \\
\hline 2001, 2004 & Tax Policy and Administration Reforms Amendments \\
\hline 2004 & $\begin{array}{l}\text { Federal Inland Revenue Service Act, } \\
\text { Companies Income Tax Act (CITA), } \\
\text { Petroleum Profit Tax Act (PPTA), } \\
\text { Personal Income Tax Act (PITA), } \\
\text { Value Added Tax Act (VAT), } \\
\text { Education Tax Act } \\
\text { Custom and Excise Tariffs (Consolidation) Act } \\
\text { National Sugar Development Act, } \\
\text { National Automotive Council Act }\end{array}$ \\
\hline 2007 & $\begin{array}{l}\text { Nigerian technology Development Agency (NITDA) Act, } \\
\text { Federal Inland Revenue Service Establishment Act }\end{array}$ \\
\hline
\end{tabular}

Despite the various reforms aimed at improving tax revenue generation, Nigeria has continued to experience unmitigated delinquency through widespread tax evasion and avoidance. That the prevailing delinquency in tax collection constitutes a major impediment to economic development and growth is hardly controvertible. Determined to resolve the contradictions in tax administration and tax compliance in Nigeria, the Federal Inland Revenue Service (FIRS) (2012) introduced the following three measures: (a) Tax Payment Identification Number (TIN) which became operational in February 2008; (b) Automated Tax System (ATS) which is used to track a taxpayer's tax position and related issues; (c) the e-payment system (EPS) to enhance tax payment procedures (FIRS 2012).

While governments - all governments - need lots of money to execute their mandates and while tax is regarded as a citizen's obligation to the state, it is widely believed that the incentive for affirmative tax compliance is the citizen's expectation in return of good governance and provision of social infrastructure (such as security, good 
roads, healthcare facilities, and other social amenities). It is the perennial failure of successive Nigerian governments, at all levels of governance, to provide good governance and efficient public services that mainly contributes to low tax compliance in Nigeria and many developing countries. An intriguing interpretation of Nigeria's conundrum is that successive governments' inattention to taxation derives from undue dependence on oil revenues and the entrenched corrupt tendencies. This contrasts with the scenario in developed countries, where tax payment is as inescapable as death. However, with dwindling oil revenues from fallen oil prices, there seems to be a renewed interest in how taxation could become a fiscal 'tour de force' in Nigeria's revenue generation. The next section overviews the theoretical framework underpinning the relations between tax reforms and economic growth.

\section{Analytical Framework and Methodology}

Any theoretical formulation about taxation must be set against the backdrop of two main considerations. First, there is a universal consensus that all tiers of government (national, state and local) need lots of revenue to finance public-sector expenditures which must be raised from a variety of sources to anchor sustainable development goals, primarily economic development, social development and environmental protection. Second, the details of taxation are guided by two principles: ability to pay and expected benefit. Any tax reforms must be anchored on these two precepts. Against this backdrop, this study seeks to examine the longitudinal effect of various tax reforms on the economic growth of Nigeria from 1971to 2014, a period spanning over four decades. We concentrate on this period because it encompasses bouts of significant tax reforms over different national governance regimes: military interregnums and uninterrupted democratic dispensation (1999 to date). This longitudinal stretch provides an ample empirical observational base for assessment of the effect of economic growth variables such as tax reforms.

We present an econometric model which is informed by standard economic theory of both classical and Keynesian genres. The model is designed to capture the impact of various forms of tax on national income and draws from Ekeocha et al. (2012) and Kandil (2002). The model expresses changes in national income [aggregate demand/supply (Note 1) as proxy for Gross Domestic Output (GDP)] as a function of growth rate of various forms of tax, namely: Company Income Tax (CIT), Personal Income Tax (PIT), Value Added Tax (VAT), Petroleum Profit Tax (PPT) and Custom and Excise Duties (CED). The analysis also captures the impact of Total Tax Revenue (TTR). The dependent variable is GDP while the independent variables are CIT, PIT, VAT, PPT, and CED. Thus, the model is expressed as:

$$
\triangle G D P=\propto_{0}+\propto_{2} \Delta C I T+\propto_{3} \Delta P I T+\propto_{4} \Delta V A T+\propto_{5} \Delta P P T+\propto_{6} \Delta C E D+\varepsilon
$$

Where: $\Delta$ denotes change and $\propto_{s}$ ' are coefficients of the respective tax bases.

To account for or capture the persistence and the dynamics of national income in the model, the one-period lag of GDP is introduced. Thus, equation (1) becomes:

$$
\triangle G D P=\propto_{0}+\propto_{1} \Delta G D P(-1)+\propto_{2} \Delta C I T+\propto_{3} \Delta P I T+\propto_{4} \Delta V A T+\propto_{5} \Delta P P T+\propto_{6} \Delta C E D n+\varepsilon
$$

The interpretative implication is this: if the estimated coefficient turns positive and statistically significant, it denotes positive impact on national income. If, on the other hand, the estimated coefficient is negative and statistically significant, it signifies negative impact on national income. From fiscal policy point of view, this consideration lends credence to the conclusion that tax reforms have positive effect on national income and GDP. Following the Keynesian model, increases in taxes are expected to lead to positive changes in the levels of key macroeconomic variables, such as GDP and national income, especially in developing countries. In the light of these considerations, the relationship between tax reforms and national income is usually examined from a long-term perspective. The Ordinary Least Square (OLS) method of estimation is used to analyse the time series data collected from Central Bank of Nigeria Statistical Bulletin between 1971 and 2014. As noted by Ezeabasili, Tsegba and Herbert (2012), the OLS is one of the most commonly used methods in econometric investigations involving large models.

\section{Econometric Results and Discussion}

The characteristics of the time series data used in the regression analysis are presented in Table 2. The table reports the summary descriptive statistics as well as the Jarque-Bera (J-B) $(1982,1987)$ tests of each variable. The motivation for the J-B test is that the normal distribution of a set of variables (with any mean or variance) has a skewness coefficient of zero, and a kurtosis coefficient of three. That is, it has zero "excess kurtosis" (Giles, 2014). If these two conditions are found to hold, then the null hypothesis of normality (H0: normality) is true and accepted as having decent power properties. In other words, the variables are good to go with. The variables are systematically distributed as supported by the descriptive statistics of the variables employed. The growth rate of 
GDP averaged 25.42, implying consistent growth in income over the study period. Similarly, the means of company income tax, personal income tax, value added tax, petroleum profit tax and custom and excise duties are positive. The mean values of all the variables are conspicuously different from their respective median values. This is an indication of high standard deviation as depicted in the table. The evidence of large variances of the variables is supported by the statistics of skewness and kurtosis. The growth rate of income and other employed variables are positively skewed, signifying relatively heavy-right tail. Similarly, all the employed variables are with excess kurtosis, suggesting higher peak than that of normal distribution (see Table 2).

Table 2. Summary of statistical properties of the variables descriptive statistics

\begin{tabular}{lccccccc}
\hline & GRGDP & GRCIT & GRVAT & GRPIT & GRPPT & GRCED & GRTTR \\
\hline Mean & 25.42232 & 26.48265 & 26.99330 & 28.72654 & 22.11041 & 25.27572 & 28.07588 \\
Median & 18.24634 & 5.599354 & 7.663404 & 18.36214 & 5.748770 & 5.666686 & 11.84562 \\
Maximum & 118.0998 & 563.0800 & 524.4282 & 175.1107 & 444.7628 & 588.8474 & 395.1828 \\
Minimum & -4.055021 & -13.74164 & -13.24592 & -6.427331 & -7.323378 & -7.686886 & -7.874174 \\
Std. Dev. & 26.23666 & 91.97520 & 87.88484 & 35.37546 & 71.25009 & 92.42254 & 65.54522 \\
Skewness & 1.979279 & 5.054828 & 4.810490 & 2.179203 & 5.134581 & 5.469270 & 4.566237 \\
Kurtosis & 7.431593 & 28.60563 & 26.05955 & 8.842350 & 29.97635 & 33.17085 & 24.68838 \\
Jarque-Bera & 64.73352 & 1389.398 & 1144.561 & 97.40273 & 1527.495 & 1888.208 & 1015.278 \\
Probability & 0.000000 & 0.000000 & 0.000000 & 0.000000 & 0.000000 & 0.000000 & 0.000000 \\
Sum & 1118.582 & 1165.236 & 1187.705 & 1263.968 & 972.8581 & 1112.132 & 1235.339 \\
Sum Sq. Dev. & 29599.59 & 363755.8 & 332121.0 & 53811.19 & 218292.7 & 367302.8 & 184735.5 \\
Observations & 44 & 44 & 44 & 44 & 44 & 44 & 44 \\
\hline
\end{tabular}

In order to determine whether the study variables are stationary series or unit roots, the variables were subjected to two types of unit roots. Non-stationary variables can yield spurious results in regression analysis. It is important to distinguish deterministic and stochastic trends because OLS regressions will show spurious relationships between time series with (deterministic or stochastic) trends (Hamilton, 1994). The test employed is the Augmented Dickey-Fuller (ADF) unit root test (Note 2). It is an augmented version of the Dickey-Fuller test of larger and more complicated set of time series models. The ADF statistic, used in the test, is a negative number. The more negative it is, the stronger the rejection of the hypothesis that there is a unit root at some level of confidence (Ibid.). The result of the ADF test is presented in Table 3. All the variables were stationary and found to be significant at the $5 \%$ level.

Table 3. Augmented dickey fuller unit root test with intercept results

\begin{tabular}{lll}
\hline Variables & t-Statistic & Prob.* \\
\hline GRGDP & -6.011892 & 0.0000 \\
GRCIT & -6.582777 & 0.0000 \\
GRVAT & -6.525206 & 0.0000 \\
GRPIT & -6.710572 & 0.0000 \\
GRPPT & -6.397841 & 0.0000 \\
GRCED & -6.544597 & 0.0000 \\
GRTTR & -6.769576 & 0.0000 \\
\hline
\end{tabular}

Note. The critical value is -2.95 at $5 \%$ significance level.

The result of the regression analysis is presented in Table 4. Growth rate of value added tax (GRVAT) and growth rate of personal income tax (GRPIT) were found to be significant in the model. Specifically, growth rate of value added tax has a negative significant effect on growth rate of income, while the growth rate of personal income tax has a positive significant effect. The negative coefficient of GRVAT $(-0.32)$ is an indication of an inverse change in growth rate of income of about three-tenths of any change in growth rate of value added tax. On the other hand, the positive coefficient of GRPIT (0.77) implies a change in growth rate of income (output) of about four-fifths due to a change in growth rate of personal income tax. Similarly, the lag value of the growth rate of income was included in the model to assess the explanatory power of past growth rate of income (GRGDP (-1)) on the behaviour of present growth rate. 
The GRGDP(-1) was found to have a significant and positive impact on the growth rate of income. Its coefficient value of 0.1 suggests one-tenth direct effect of its change on growth rate of income. The coefficients of growth rate of value added tax, personal income tax and lagged value of income growth were all statistically significant at 5\% level. The coefficients of growth rate of company income tax and petroleum profit tax were positive but not statistically significant. Also the coefficient of custom and excise duties was negative but not statistically significant. With F-statistic of 112.06, the model was both statistically robust and significant at 5\% level. The Adjusted R2 value of 0.94 indicates that $94 \%$ of the variations in growth rate of income are explained by the variables included in the model. The high value of the Durbin-Watson (DW) indicates that the model is free of first-order serial-correlation problem. Finally, the relatively low value of the standard error is an evidence of the goodness of fit of the equation.

Table 4. Regression results for the impact of tax bases on national income

\begin{tabular}{ccccc}
\hline Variable & Coefficient & Std. Error & t-Statistic & Prob. \\
\hline GRGDP(-1) & 0.103195 & 0.038977 & 2.647567 & 0.0120 \\
GRCIT & 0.146910 & 0.177135 & 0.829369 & 0.4124 \\
GRVAT & -0.323906 & 0.152290 & -2.126910 & 0.0404 \\
GRPIT & 0.767115 & 0.036252 & 21.16075 & 0.0000 \\
GRPPT & 0.337621 & 0.205229 & 1.645092 & 0.1087 \\
GRCED & -0.126450 & 0.180802 & -0.699383 & 0.4888 \\
C & 1.762467 & 1.663062 & 1.059772 & 0.2963 \\
\hline R-squared & 0.949180 & Mean dependent var & 25.41033 \\
Adjusted R-squared & 0.940710 & S.D. dependent var & 26.54705 \\
S.E. of regression & 6.464073 & Akaike info criterion & 6.718296 \\
Sum squared resid & 1504.233 & Schwarz criterion & 7.005003 \\
Log likelihood & -137.4434 & Hannan-Quinn criter. & 6.824025 \\
F-statistic & 112.0641 & Durbin-Watson stat & 2.411658 \\
Prob(F-statistic) & 0.000000 & \multicolumn{2}{c}{}
\end{tabular}

Note. $5 \%$ significance level.

A schematic OLS tracking of the forecast growth rate of GDP versus the actual GDP growth over the period is presented in Figure 1. The evidence of nil bias proportion in the graph is supported by the low variance proportion and low inequality coefficient.

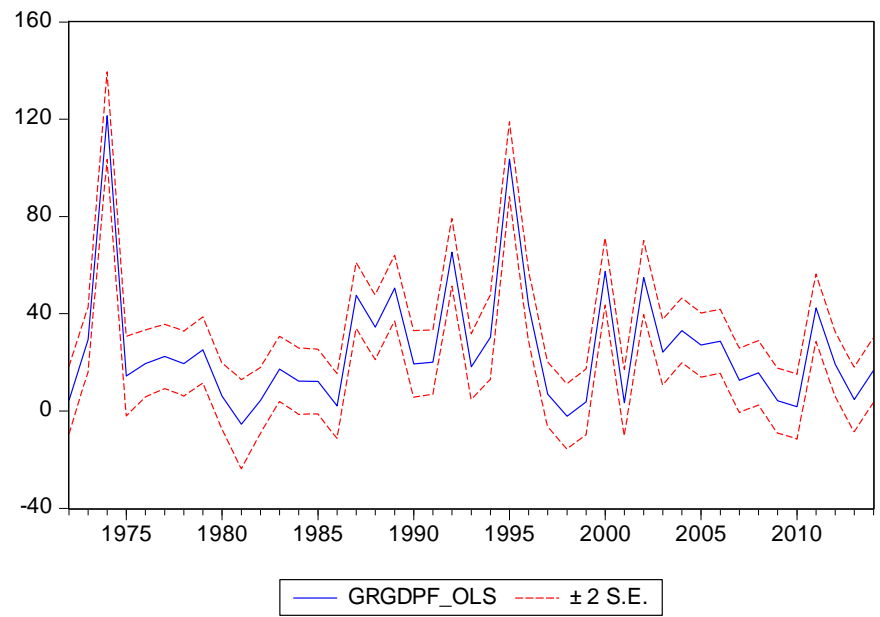

Forecast: GRGDPF_OLS

Actual: GRGDP

Forecast sample: 19712014

Adjusted sample: 19722014

Included observations: 43

Root Mean Squared Error $\quad 5.810561$

Mean Absolute Error $\quad 4.345119$

Mean Abs. Percent Error $\quad 40.76030$

Theil Inequality Coefficient 0.080075

Bias Proportion $\quad 0.000000$

Variance Proportion $\quad 0.013826$

Covariance Proportion $\quad 0.986174$

Figure 1. Graph of GDP growth rate: 1971-2014 vs 1972-2014

\section{Summary and Recommendations}

The impact of tax reforms on national economic growth has long been of interest in macroeconomics. However, the nature of this relationship or impact has remained a subject of empirical interest. In this paper, we 
investigated the long-run impact of various forms of taxation in Nigeria over a period of four decades, from 1971 to 2014. Specifically, the study investigated the nature of the impact of value added tax, personal income tax, company income tax, custom and excise duties and petroleum profit tax on national income in Nigeria. The model used in this study expressed the growth rate of national income as a function of growth rates of company income tax, personal income tax, value added tax, petroleum profit tax and custom and excise duties. These independent variables are the most critical and contentious forms of taxation in any country. A regression model was used to quantify the impact of growth in various forms of taxes on income growth in Nigeria. Diagnostic tests (F-statistics, Adjusted R-Square and Durbin-Watson) were carried out to ascertain the robustness of the parameter estimates.

The study found that growth rate of value added tax and growth rate of personal income tax have a positive significant impact on growth of national income. We also found that growth rate of value added tax has a negative significant effect on growth rate of income, while the growth rate of personal income tax has a positive significant effect on growth rate of income. The result also revealed that the past value of growth rate of income was significant and exerts positive impact on the growth rate of income. It is interesting to note that the coefficients of growth rate of company income tax and petroleum profit tax were positive in the model, but were not statistically significant. Also the coefficient of custom and excise duties was negative, but not statistically significant.

Based on the findings, the study makes the following recommendations. A leading fiscal policy need is for more attention to those taxes that seem insignificant in terms of contribution to national income. The economic properties of mild or low imposition of duty on imported goods can be fully established only after the adverse consequences of smuggling on government collectible revenue is assessed. Also, many tax reforms have been carried out in the past three decades, the outcome of which left much to be desired because some of the reforms were carried out on ad hoc basis. However, the reform of the early 90s had a meaningful impact on overall tax performance, as is evidently manifested in our findings. Consequently, this study suggests the consolidation and sustainability of the value added tax and personal income tax reforms.

The foregoing research findings have both microeconomic and macroeconomic implications. Tax policy has a significant influence on the behaviour of economic entities and the national income in Nigeria. Accordingly, tax policy is important in fostering the growth of national income in Nigeria. This consideration compels policy makers to give requisite attention to tax policy issues, especially in relation to associated reforms. Although not much of tax reform was achieved during the spate of military interregnums that characterized much of 1960 to 1999, there is still a widespread belief that political obstacles have continued to hinder progressive tax reforms since Nigeria's return to democracy in 1999. Strong political actors in active collusion with economic elites continue to monopolise the political-economic space in defence of their economic interests. Not only is the incidence of tax avoidance and evasion rampant but is aided by the strong capacity of their businesses and interests to influence policy decisions in cross-sectoral areas.

\section{References}

Ajakaiye, D. O., \& Odusola, A. F. (1996). Price Effects of value added tax in Nigeria. NCEMA Policy Analysis Series, 2(2), 48-68.

Baye, M. R., \& Jansen, D. W. (2006). Money, Banking, and Financial Markets: An Economics Approach. India: AITBS Publishers.

Bera, A. K., \& Jarque, C. M. (1982). Model specification tests: A simultaneous approach. Journal of Econometrics, 20, 59-82. http://dx.doi.org/10.1016/0304-4076(82)90103-8

Brown, D. (2002). Canada's Conundrum: Tax and Spending. Canadian Tax Journal, 50(4), 1322-1332.

Central Bank of Nigeria (CBN). (2015). Statistical Bulletin and Annual Report and Statement. Abuja: Central Bank of Nigeria.

Dahl, H., \& Mitra, P. (1991). Applying Tax Policy Models in Country Economic Work: Bangladesh, China, and India. The World Bank Economic Review, 5(3), 553-572. http://dx.doi.org/10.1093/wber/5.3.553

Dickey, D. A., \& Fuller, W. A. (1979). Distribution of the estimators for autoregressive time series with a unit root. Journal of the American Statistical Association, 74, 427-431.

Ekeocha, P. C., Ekeocha, C. S., Malaolu, V., \& Oduh, M. O. (2012). Revenue Implications of Nigeria's Tax System, Journal of Economics and Sustainable Development, 3(8), 206-215.

Ezeabasili, V. N., Tsegba, I. N., \& Herbert, W. E. (2012). Economic Growth and Fiscal Deficits: Empirical 
Evidence from Nigeria. Economics and Finance Review, 2(6), 85-96. Retrieved from http://www.businessjournalz.org/efr

Ezeoha, A. E., \& Ogamba, E. O. (2010). Corporate Tax Shield or Fraud? Insight from Nigeria. International Journal of Law and Management, 52(1), 5-20. http://dx.doi.org/10.1108/17542431011018516

FIRS. (2012). Excerpts of the Handbook: Federal Inland Revenue Service and Taxation Reforms in Democratic Nigeria. Abuja: Federal Inland Revenue Service.

Fuller, W. A. (1996). Introduction to Statistical Time Series (2nd ed.). New York: Wiley.

Giles, D. E. (2014). Some Things You Should Know About the Jarque-Bera Test. Econometrics Beat: Dave Giles' Blog, February 15.

Hamilton, J. D. (1994). Time Series Analysis. Princeton: Princeton University Press.

Jarque, C. M., \& Bera, A. K. (1987). A test for normality of observations and regression residuals. International Statistical Review, 55, 163-172. http://dx.doi.org/10.2307/1403192

Jhingan, M. L. (1995). The Economics of Development and Planning. New Delhi: Prabhat Offset Press.

Kaldor, N. (1964). Will Underdeveloped Countries Learn How to Tax? Essays on Economic Policy, 1, 253-268.

Kandil, M. (2002). Macroeconomic Shocks and Dynamics in the Arab World. IMF/University of Wisconsin, Milwaukee. WI 53201.

Leyira, C. M., Chukwumma, E., \& Asian, A. U. (2012). Tax System in Nigeria: Challenge and the Way Forward. Research Journal of Finance and Accounting, 3(5), 9-15.

Musgrave, R. A. (1969). Fiscal Systems. New Haven: Yale University Press.

Musgrave, R. A., \& Musgrave, P. (2004). Public Finance in Theory and Practice. India: Tata McGraw-Hill.

Odusola, A. (2006). Tax policy Reforms in Nigeria. World Institute for Development Economics Research, Paper No. $2006 / 03$.

OECD. (2010). Tax Policy Reform and Economic Growth. OECD Tax Policy Studies, (20). OECD Publishing. http://dx.doi.org/10.1787/9789264091085-en

Ogbonna, G. N., \& Appah, E. (2012). Impact of Tax Reforms and Economic Growth of Nigeria: A Time Series Analysis. Current Research Journal of Social Sciences, 4(1), 62-68.

Padovano, F., \& Galli, E. (2002). Comparing the growth effects of marginal vs. Average tax rates and $\begin{array}{lllll}\text { progressivity. European Journal of Political Economy, } 18, & 529-544 .\end{array}$ http://dx.doi.org/10.1016/S0176-2680(02)00104-0

Somorin, T. (2012). Overview of the Nigeria tax System stakeholders, Issues and Challenges. Paper Presented at the Chartered Institute of Taxation of Nigeria Mandatory Professional Training Programme, Enugu.

Toye, J. F. J. (1978). Taxation and Economic Development. London: Frank Cass \& Co. Ltd.

Ukeje, S. (2010). Lessons of the global financial and economic crisis for fiscal policy and public expenditure management in Nigeria. The Global Economic Crisis and Nigeria. Enugu. African Institute for Applied Economics.

Wang, D. (2007). Convergence Tests on Tax Burden and Economic Growth among China, Taiwan and the OECD Countries. Physica, 380, 278-286. http://dx.doi.org/10.1016/j.physa.2007.02.046

Wilford, S. D., \& Wilford, W. T. (1978). Estimates of Revenue Elasticity and Buoyancy in Central America: 1955-1974. In J. F. J. Toye (Ed.), Taxation and Economic Development. London: Frank Cass \& Co. Ltd.

Wing, I. S. (2006). Computable General Equilibrium Models and Their Use in Economy-Wide Policy Analysis. MIT Joint Program on the Science and Policy of Global Change Technical Note No. 6 September.

\section{Notes}

Note 1. Both aggregate supply and demand are the same at the equilibrium.

Note 2. Dickey and Fuller (1979) developed a procedure for testing whether a variable has a unit root or, equivalently, that the variable follows a random walk. The null hypothesis is always that the variable has a unit root. 


\section{Copyrights}

Copyright for this article is retained by the author(s), with first publication rights granted to the journal.

This is an open-access article distributed under the terms and conditions of the Creative Commons Attribution license (http://creativecommons.org/licenses/by/3.0/). 